\title{
Physiology of the Meishan boar
}

\author{
D. D. Lunstra ${ }^{1}$, J. J. Ford ${ }^{1}$, J. Klindt ${ }^{2}$ and T. H. Wise ${ }^{1}$ \\ USDA, ARS, 'Reproduction Research Unit and ${ }^{2} N$ utrition Research Unit, \\ R. L. Hruska US Meat Animal Research Center, Clay Center, Nebraska 68933-0166, USA
}

\begin{abstract}
Onset of puberty (sperm production) occurs at a much younger age (56-84 days) in Meishans than in conventional boars (120-180 days). Throughout postnatal development, Meishans exhibit markedly higher (two- to ten-fold) concentrations of serum FSH, LH and androgens compared with conventional boars, and these high hormone concentrations are maintained at maturity. Increased gonadotrophin concentrations occur only in Meishan males, since concentrations in female Meishans and conventional females do not differ. In the Meishan boar, FSH increases steadily during establishment of sperm production and $\mathrm{LH}$ increases markedly after tubule diameter stabilizes, while FSH and LH concentrations are low and change little during this period of rapid testicular growth in conventional boars. The proportion of the testis occupied by Leydig cells is two-fold greater and average Leydig cell size is two- to four-fold larger in Meishans than in conventional boars during the onset of spermatogenesis and into maturity. Testis size in Meishans is only half that of conventional boars at maturity, and the number of Sertoli cells is markedly reduced in Meishans. However, Meishan testes exhibit reduced degeneration of germ cells and spermatids during spermatogenesis, and spermatogenic efficiency per Sertoli cell in Meishans is double that in conventional boars. At maturity, Meishan pituitaries have greater mass, larger gonadotrophs, higher content of FSH, and greater expression of genes for FSH and LH subunits than found in conventional boars. The high concentrations of serum gonadotrophins in the mature Meishan exhibit a typical postcastration rise, respond to $\mathrm{GnRH}$ stimulation and are suppressed by gonadal steroids, indicating that the hypothalamo-pituitary-gonadal axis functions normally but with much higher set points in Meishan boars. These unusual endocrine and physiological attributes in boars of the highly prolific Meishan breed offer a unique model for further investigation of factors influencing early onset of puberty and efficiency of male reproductive function.
\end{abstract}

\section{Introduction}

There are over 75 breeds of pig in China today; some of these have been selected for over 7000 years ( $\mathrm{Li}$ and Enfield, 1989). Hierarchical classification of Chinese breeds based on geographic distribution, history, body size, physical appearance and reproductive characteristics identified one group, known as Taihu pigs, which were characterized by high rates of reproduction and average size ( $\mathrm{Li}$ and Enfield, 1989). Taihu pigs originate from the Lake Taihu region west of Shanghai in southern China. Meishans are typical of this group; they exhibit early sexual maturity and high prolificacy (Cheng, 1983; Wang, 1990). The importation of Meishan pigs into France (1979), the United Kingdom (1987), United States (1989) and other countries allowed research that documented greater prolificacy in Meishans than in conventional pigs of these countries, averaging three to five more pigs per litter (Haley et al., 1995). Female Meishans reach puberty at very young ages (85-118 days of age), at least 3-4 months earlier than pubertal age (200-235 days of age) in conventional pigs (Wang, 1990; Christenson, 1993; Hunter et al., 1993; White et al., 1993). In this review, conventional breeds refers to typical pig breeds of US and European origin. Meishan boars, compared with 
conventional breeds of pig, offer a unique model for investigation of factors influencing male reproductive function that relate to high prolificacy, but only limited data on pubertal development and mature reproductive function have been reported for these boars. In addition, no study has characterized relationships between testicular structure and endocrine function in Meishan boars. The purpose of this review is to summarize results on pubertal development, endocrinology, and mature reproductive function in Meishan boars and to compare these with observations in conventional breeds of boar to provide insights concerning the primary mechanisms controlling reproductive function in male pigs.

\section{Testicular Development and Onset of Sperm Production in Meishan Boars}

During pubertal development in Meishan boars, body weight (BWT), paired testis weight (PTW) and epididymal weights increase continuously from birth to 16 weeks of age (Fig. 1; Harayama et al., 1991; Lunstra et al., 1993). The testis exhibits a typical rapid increase in mass associated with pubertal development beyond 6 weeks of age (Fig. 1). Elongated spermatids first appear within seminiferous tubules at 6 weeks of age, and homogenization-resistant spermatid nuclei consistently occur in the testes by 8 weeks of age (BWT $=10.3 \mathrm{~kg}$, PTW $=30.9 \mathrm{~g}$ ), which is slightly earlier than the appearance of elongated spermatids at 60-75 days of age reported for Meishan boars in Japan (Harayama et al., 1991). Percentage of tubules exhibiting elongated spermatids increases steadily and $>80 \%$ have elongated spermatids by 12 weeks of age (BWT $=19.2 \mathrm{~kg}$, PTW $=63.3 \mathrm{~g}$ ). Lumina are first observed in seminiferous tubules at 4 weeks of age; the majority of tubules exhibit lumina by 6 weeks; and spermatozoa are present in the lumina of seminiferous tubules at 8 weeks. Thus, onset of spermatogenesis (spermatozoa formed and released into the lumen of the seminiferous tubules) in the Meishan occurs at 8 weeks of age (Fig. 1). Spermatozoa first appear in the cauda epididymis at 8 weeks of age; first motile spermatozoa (about $20 \%$ motile) are present by 10 weeks of age, and appreciable sperm motility ( $>70 \%$ motile) is attained by 14 weeks and beyond, which is in agreement with results of other workers (Cheng, 1983; Wang, 1990; Harayama and Kato, 1992).

Onset of sperm production (puberty) in Meishan boars occurs much earlier (56-84 days) and at lower testis weight (30-60 g PTW) compared with the 120-180 days of age and 160-240 $\mathrm{g}$ PTW at puberty reported for various breeds of conventional boar (FlorCruz and Lapwood, 1978; Allrich et al., 1982, 1983; Colenbrander et al., 1982; Ford, 1983; Young et al., 1986; Lee et al., 1987; Kosco et al., 1987; Trudeau et al., 1992). Data from Meishans extend the range of differences among breeds within a species for body weight and testis weight at given ages during pubertal development (Young et al., 1986). In addition, puberty occurs earlier in males than in females, even within the Meishan, since puberty in Meishan boars occurs 30-60 days earlier than in Meishan females.

\section{Changes in Testicular Structure During Pubertal Development in Meishan Boars}

During postnatal testicular development in Meishan boars, the patterns of change in diameter of seminiferous tubules and in volume percentages of the testis occupied by tubules, interstitial tissue and Leydig cells (Fig. 1) are very similar to patterns exhibited by conventional boars but are more compressed in time. The diameter of seminiferous tubules in the Meishan is low at birth (about 70 $\mu \mathrm{m}$ ), increases rapidly and linearly through first sperm production (about $200 \mu \mathrm{m} ; 8$ weeks), and reaches a plateau by 12 weeks of age and thereafter at 250-290 $\mu \mathrm{m}$ (Fig. 1 and Table 1; Harayama et al., 1991). Tubule diameter in conventional boars is also small at birth (about $60 \mu \mathrm{m}$ ), increases peripubertally and reaches a plateau at approximately 24 weeks of age and beyond (FlorCruz and Lapwood, 1978; van Straaten and Wensing, 1977; Allrich et al., 1983). Maximal tubule diameter tends to be larger in Meishan (250-290 $\mu \mathrm{m})$ than in conventional boars (190-257 $\mu \mathrm{m}$; Table 1; FlorCruz and Lapwood, 1978; van Straaten and Wensing, 1977; Allrich et al., 1983; Lee et al., 1987). Appearance of lumina in seminiferous tubules indicates establishment of the blood-testis barrier; thus this barrier is established at a markedly younger age in Meishan (about 40 days of age) than in conventional boars 

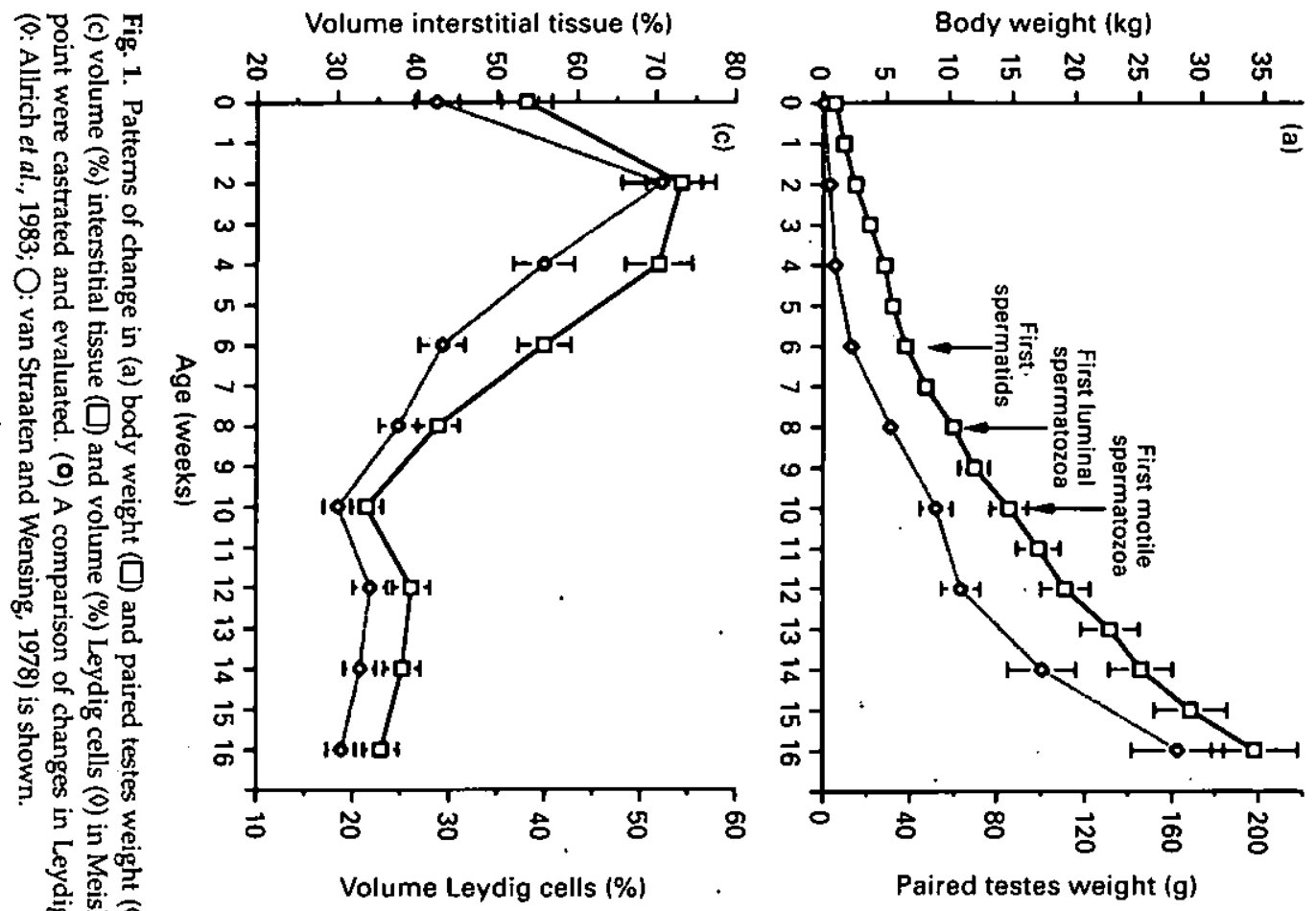

艿 พ.

울.

与.

吃

总容

然

2 ?

육

它

5 苋

3 残

密

행을

잉

言㐘急.

8 究究.

罗

马

总芯

要

윰 융

Leydig cell volume $\left(\mu \mathrm{m}^{3}\right)$ (Meishan)

Seminiferous tubule diameter $(\mu \mathrm{m})$
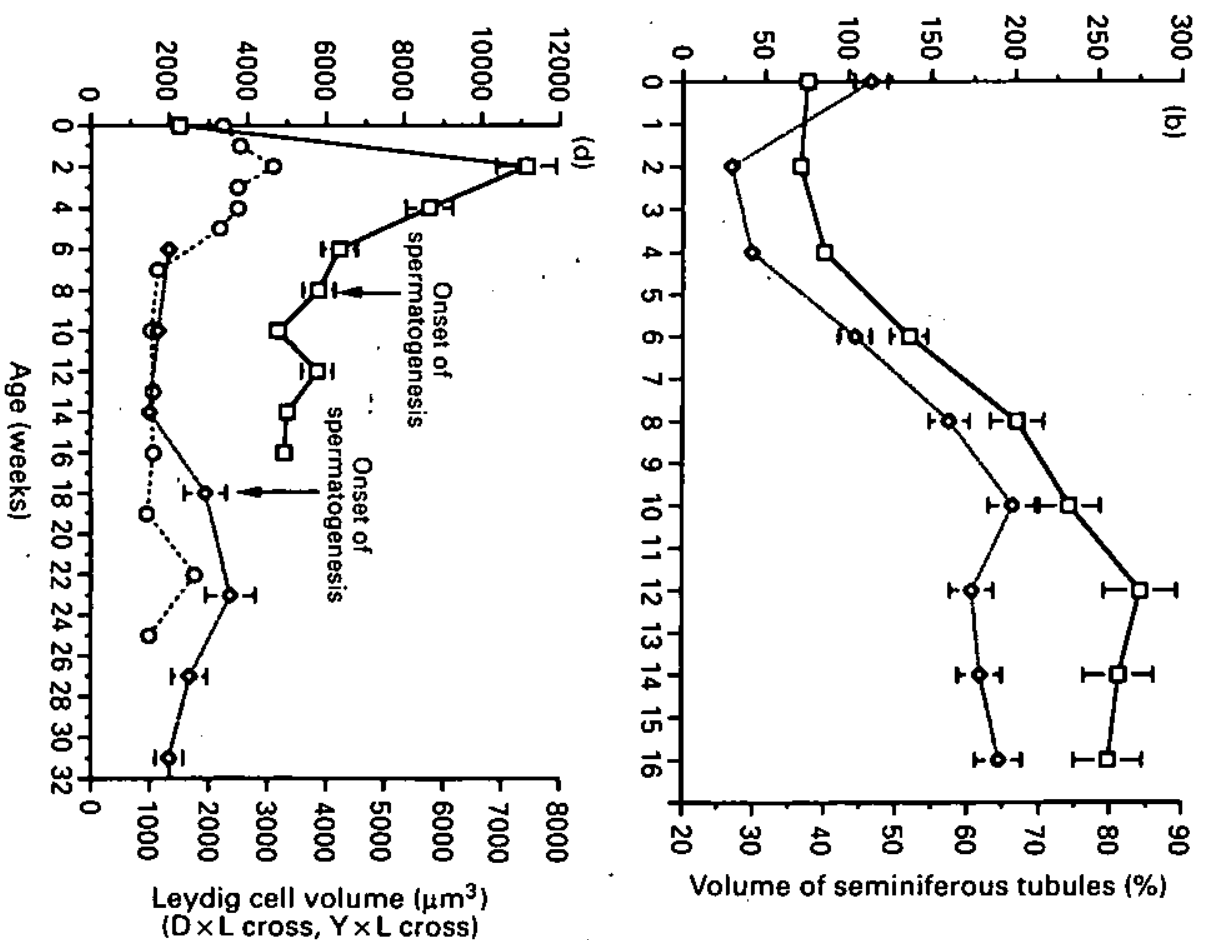
Table 1. Differences between mature Meishan and conventional boars in size of testes, sperm production and various aspects of testicular structure ${ }^{a}$

\begin{tabular}{|c|c|c|}
\hline & $\begin{array}{c}\text { Meishan } \\
(n=5)\end{array}$ & $\underset{(n=5)}{\text { Composite }^{b}}$ \\
\hline Age (days) & $225 \pm 3$ & $346 \pm 2$ \\
\hline Body weight $(\mathrm{kg})$ & $78 \pm 2$ & $133 \pm 6$ \\
\hline Paired testes weight $(\mathrm{g})$ & $269 \pm 19$ & $541 \pm 35$ \\
\hline Volume (\%) seminiferous tubules & $48.6 \pm 1.7$ & $68.7 \pm 1.6$ \\
\hline Volume (\%) interstitial tissue & $51.4 \pm 1.9$ & $31.3 \pm 0.8$ \\
\hline Volume (\%) Leydig cells & $18.5 \pm 0.6$ & $7.1 \pm 0.2$ \\
\hline Volume $(\%)$ vascular & $10.0 \pm 0.9$ & $6.5 \pm 0.8$ \\
\hline Seminiferous tubules, diameter $(\mu \mathrm{m})$ & $287 \pm 15$ & $257 \pm 8$ \\
\hline Daily sperm production $/ g^{-1}$ testis & $24.47 \pm 1.26$ & $24.77 \pm 1.43$ \\
\hline Total daily sperm production ${ }^{d}$ & $6.04 \pm 0.52$ & $12.46 \pm 1.43$ \\
\hline Total no. Sertoli cells ${ }^{d}$ & $3.87 \pm 0.59$ & $14.45 \pm 1.33$ \\
\hline DSP per Sertoli cell & $1.56 \pm 0.32$ & $0.86 \pm 0.20$ \\
\hline Total no. Leydig cells ${ }^{d}$ & $15.27 \pm 0.66$ & $34.79 \pm 1.76$ \\
\hline Leydig cell size $\left(\mu \mathrm{m}^{3}\right)$ & $2855 \pm 124$ & $960 \pm 49$ \\
\hline
\end{tabular}

"Calculated from data of Okwun et al. (1996a,b). All data shown are presented as means \pm SEM. Volume (\%): volume percentage of testicular parenchyma occupied by respective structure or cell type.

'Composite boars: crossbred boars (1/4 Chester White, 1/4 Landrace, 1/4 Large White, 1/4 Yorkshire). Each mean \pm SEM for Meishan differs $(P<0.10$ to $P<0.01)$ from that for Composite boars, except $(P>0.20)$ for average tubule diameter and daily sperm production $\mathrm{g}^{-1}$ testis.

'Daily sperm production (DSP) $\times 10^{6}$ per gram of testicular parenchyma.

${ }^{\circ}$ Total daily sperm production (TDSP) $\times 10^{9}$ per paired testes. Total number of Sertoli cells $\times 10^{9}$ per paired testes. Total number of Leydig cells $\times 10^{9}$ per paired testes.

(90-120 days; FlorCruz and Lapwood, 1978; Allrich et al., 1983; Colenbrander et al., 1982). Rapid proliferation of Sertoli cells occurs primarily during the first month after birth in conventional boars (Tran et al., 1981; Kosco et al., 1987), and establishment of the blood-testis barrier indicates cessation of proliferation of Sertoli cells thereby defining the total population of Sertoli cells and maximum mature testis size (Russell et al., 1990; Chubb, 1992). The markedly earlier onset of puberty in the Meishan requires curtailment of Sertoli cell proliferation sooner in the early postnatal period. Indeed, at sexual maturity, Meishan boars have substantially smaller paired testis weight and fewer Sertoli cells than do conventional boars (Table 1 ).

In Meishan (Fig. 1) and conventional boars, the percentage of the testis occupied by total interstitial tissue and by Leydig cells exhibits a major early postnatal peak at 1-4 weeks of age followed by a rapid decline through onset of puberty and maintenance at reduced values after puberty (van Straaten and Wensing, 1977, 1978; FlorCruz and Lapwood, 1978; Colenbrander et al., 1982; Allrich et al., 1983). While similar in pattern of change, the absolute values for volume percentage of the testis occupied by interstitial tissue (35-50\%) and by Leydig cells (15-25\%) in Meishan boars beyond 10 weeks of age and into maturity remains substantially greater than the values reported for conventional boars beyond 20 weeks of age (15-30\% interstitial, 7-10\% Leydig, respectively). Thus, during the latter part of pubertal development and into maturity (Table 1), Meishan boars consistently exhibit a 1.5- to 2.5-fold higher proportion of the testes occupied by interstitium and Leydig cells than do conventional boars.

Average volume per Leydig cell, in both Meishan (Fig. 1 and Table 1) and conventional boars, exhibits a major early postnatal peak at $1-4$ weeks of age, followed by a reduction in size, a transient increase during onset of spermatogenesis, and a slow decline in size that is maintained into maturity (van Straaten and Wensing, 1977, 1978; FlorCruz and Lapwood, 1978; Colenbrander et al., 1982; Allrich et al., 1983). Despite the similarity in pattern, absolute values for Leydig cell size in the 
Meishan are markedly larger than in other breeds (Fig. 1 and Table 1), and average two- to four-fold larger at every age examined than reported values for Leydig cell size in conventional boars (van Straaten and Wensing, 1978; Peyrat et al., 1981; Allrich et al., 1983; Lunstra et al., 1986). Concomitant with the increase in cell size, increases in average volume of the nucleus, number of mitochondria and amount of endoplasmic reticulum occur within Leydig cells of Meishan testis (Lunstra, unpublished data), and increases in these intracellular components generally reflect increased steroid-synthesizing capacity (Zirkin et al., 1980; Lunstra et al., 1986). Leydig cell size in conventional boars declines and remains small (smaller than at birth) between 6 and 16 weeks of age before increasing transiently coincident with increasing spermatogenesis (18-26 weeks of age). Meishans also exhibit a less noticeable increase coinciding with increasing spermatogenesis (12 weeks of age) and both the percentage interstitial tissue and Leydig cells exhibit small but consistent increases at 12 and 14 weeks of age (Fig. 1). Thus, the early postnatal and pubertal peaks occur so close together in the Meishan, and overall Leydig cell size is so much larger, that a pronounced regression in prepubertal Leydig cell volume does not occur, and the rebound in Leydig cell size at puberty is relatively small (Fig. 1).

\section{Endocrinology During Pubertal Development in Meishan Boars}

In Meishan boars, serum FSH, LH, testosterone and dehydroepiandrosterone sulfate (DHEAS) concentrations all change markedly and exhibit distinct patterns during pubertal development (Fig. 2). One striking characteristic in Meishans is that serum concentrations of all four hormones (FSH, LH, testosterone and DHEAS) are each substantially higher (two- to ten-fold) throughout postnatal development, both before and after puberty, than in conventional boars, as assayed in our laboratory (Table 2, and unpublished data) or reported by others for various breeds of conventional boar (Tan and Raeside, 1980; Allrich et al., 1982, 1983; Colenbrander et al., 1982; Ford, 1983; Schinckel et al., 1984; Kosco et al., 1987; Trudeau et al., 1992).

A major peak in serum concentrations of FSH (1-2 weeks of age), LH (3-4 weeks of age) and androgens (3-4 weeks of age) occurs early in the postnatal period in Meishan boars (Fig. 2). Although the early postnatal peak in testosterone appears to be quite subtle (Fig. 2), the increase in serum testosterone concentrations at 3-4 weeks of age is significantly higher than that during the preceding ( 2 week) and following ( 5 week) time frames. Early postnatal peaks in serum hormones also occur at comparable ages or even slightly earlier in conventional boars (Colenbrander $e t$ al., 1982; Kosco et al., 1987; Trudeau et al., 1992; Ford et al., 1997), although absolute values are lower (Fig. 2; note smaller scale of $y$-axis for conventional boars). After the early postnatal peak, serum concentrations of gonadotrophins and androgens decline at least until the onset of puberty in both Meishan ( 8 weeks) and conventional boars (16 weeks). However, with onset of spermatogenesis in Meishans, serum FSH, testosterone and DHEAS all increase steadily and markedly during the period of increasing testis mass (Figs 1 and 2), and very high concentrations of these hormones are maintained in adulthood (Table 2). Serum concentrations of LH in Meishans also increase markedly, but the increase is delayed until maximum tubule diameter is achieved (Figs 1 and 2). In contrast, after the early postnatal peak in conventional boars, serum FSH remains relatively low through puberty and on through sexual maturity, although a small increase in FSH immediately preceding or coinciding with the onset of sperm production has been reported in conventional boars (Colenbrander et al., 1982; Schinckel et al., 1984; Kosco et al., 1987; Trudeau et al., 1992; Mariscal et al., 1996), and serum concentrations of LH remain low into adulthood with no significant peripubertal changes (Allrich et al., 1982; Colenbrander et al., 1982; Schinckel et al., 1984; Kosco et al., 1987). Despite the large differences among breed in serum concentrations of hormones, it is surprising that serum LH declines before and changes relatively little during the onset of spermatogenesis in both Meishan and conventional boars (Fig. 2).

The highest peripubertal concentrations of FSH, LH, testosterone and DHEAS all occur postpubertally at 15-16 weeks of age in Meishan boars. Although serum LH concentrations decline somewhat between 16 weeks of age and maturity in Meishan boars (compare Fig. 2 and Table 2), the 


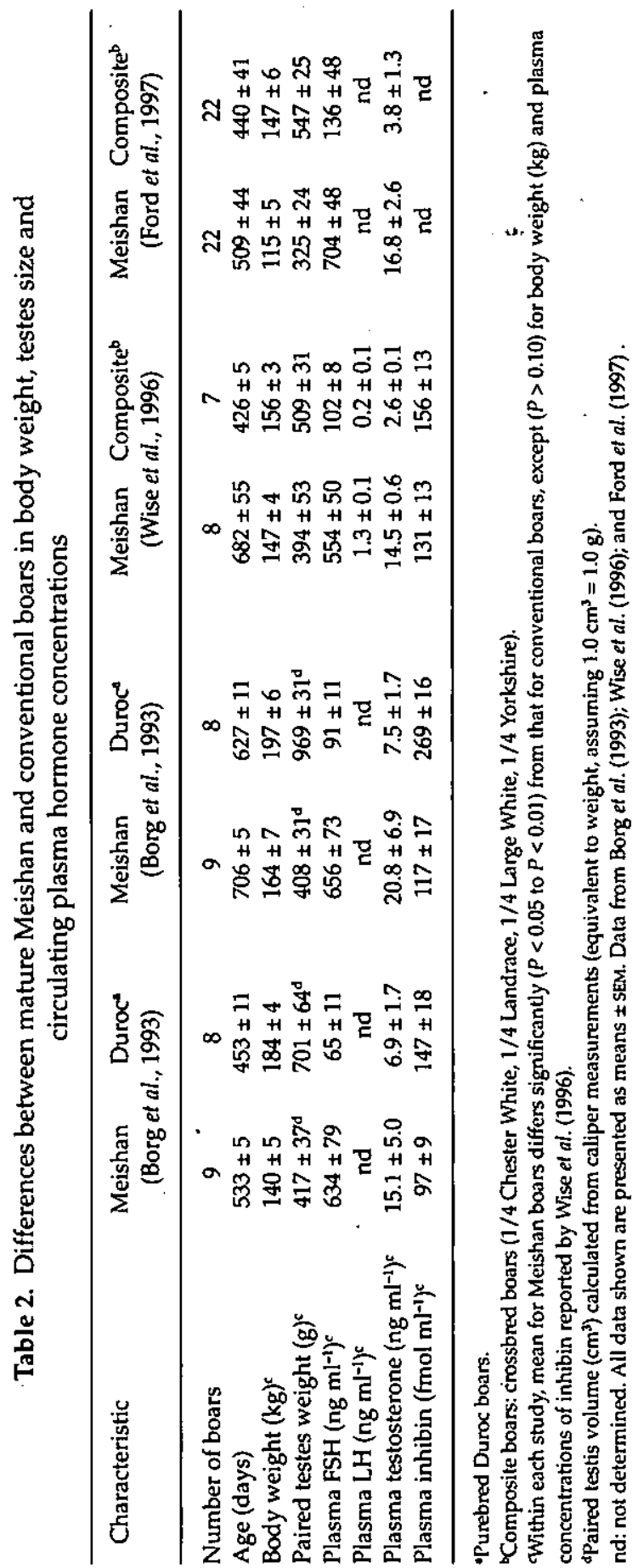



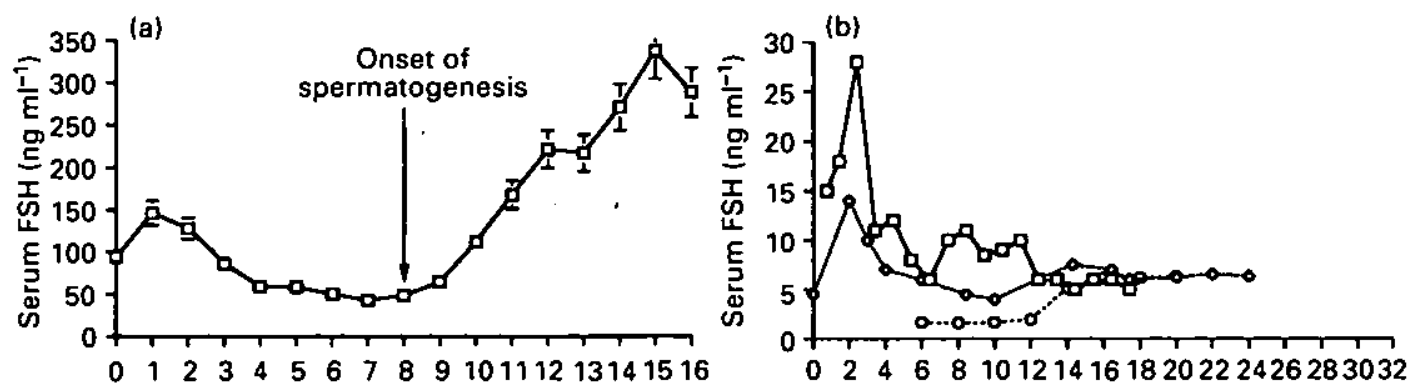

(c)

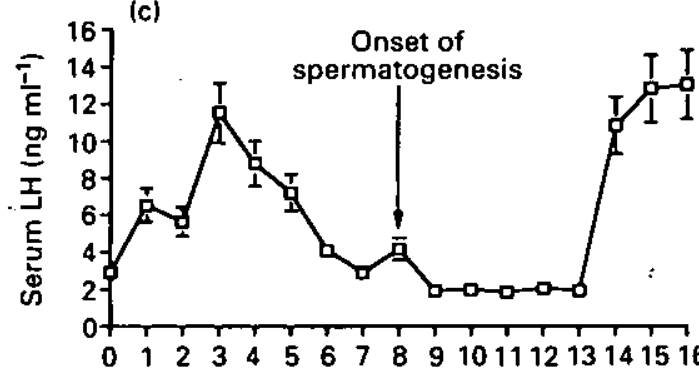

(d)
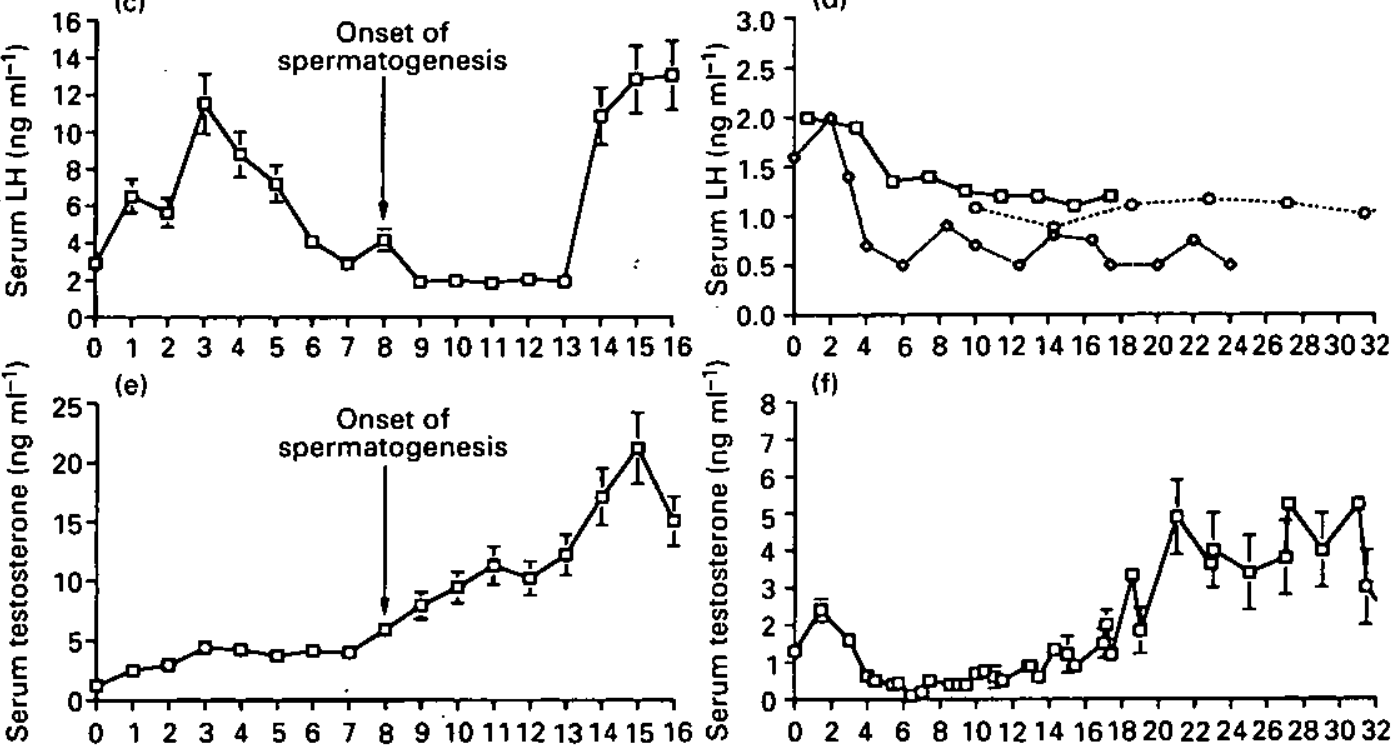

(g)
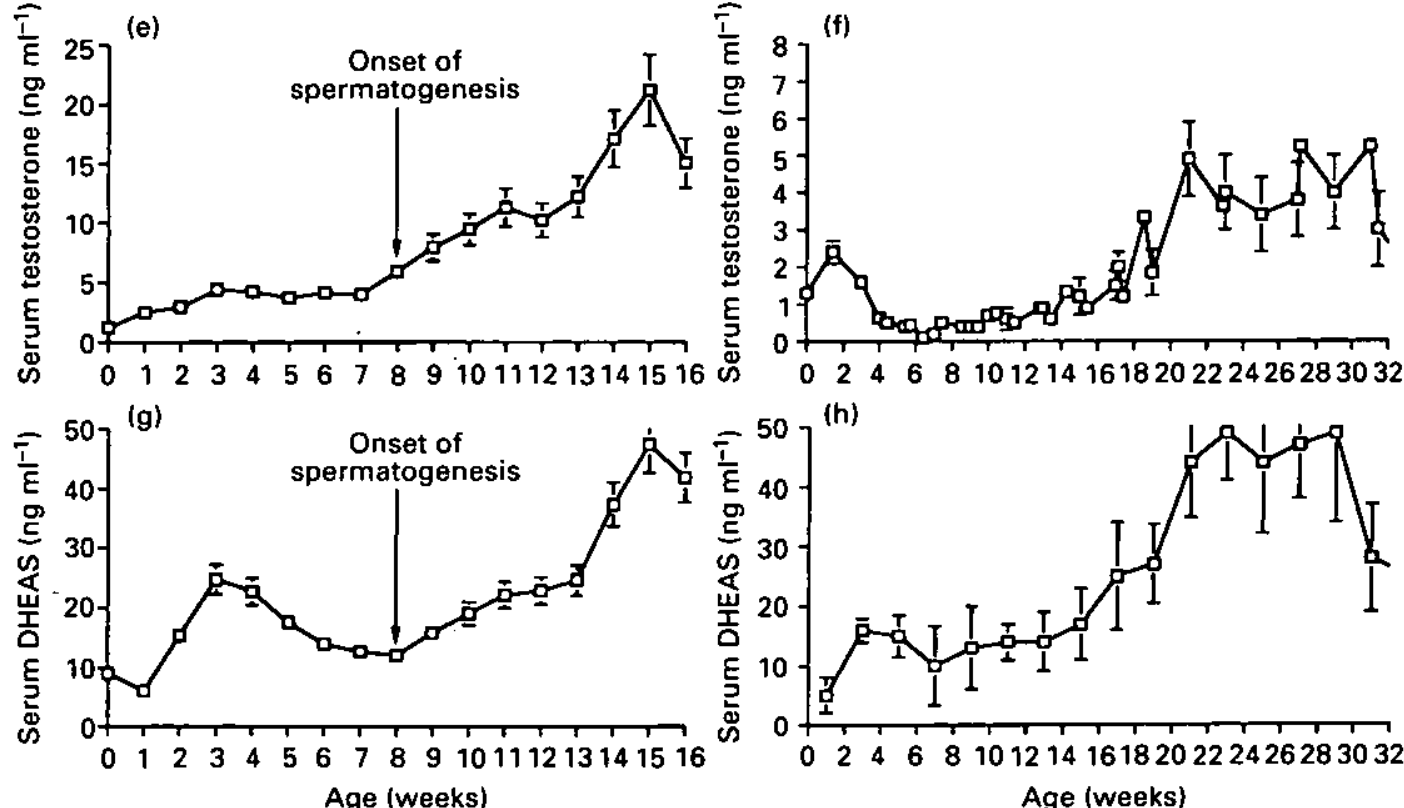

04268101214161820222426283032

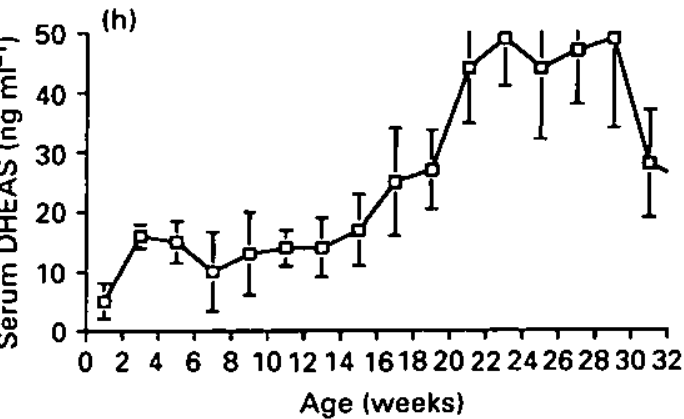

Fig. 2. Patterns of change in (a,b) FSH, $(c, d) \mathrm{LH},(e, f)$ testosterone and $(g, h)$ dehydroepiandrosterone sulfate (DHEAS) concentrations in $(a, c, e, g$,$) Meishan and (b, d, f, h$,$) conventional boars from birth through puberty.$ (b) Data from (D) Kosco et al., 1987; (0) Colenbrander et al., 1982; and (0) Schinckel et al., 1984; (d) data from () Kosco et al., 1987; (仓) Colenbrander et al., 1982 and (O) Allrich et al., 1982; (f) data combined from Tan and Raeside (1980), Allrich et al. (1982), Ford (1983) and Kosco et al. (1987); (h) data from Tan and Raeside (1980).

higher serum concentrations of $\mathrm{FSH}, \mathrm{LH}$, and testosterone present at 16 weeks of age are maintained at sexual maturity (Table 2). One possible explanation is that the sensitivity of the hypothalamus to steroid feedback in the Meishan boar may be greatly reduced during this time frame (14-16 weeks of age), but the reduction must be temporary, since feedback sensitivity seems to be fully functional at sexual maturity (see discussion on sexual maturity below). Regardless of the mechanism, Meishan 
boars continue to exhibit greater concentrations of serum FSH, LH, and androgens than do conventional boars at sexual maturity (Table 2).

In Meishan and conventional boars, the major early postnatal peaks in serum concentrations of FSH, LH and androgens coincide well with the timing of early postnatal peaks observed in volume percentages of the testis occupied by interstitial tissue and Leydig cells, and with the marked early peak in Leydig cell size (compare Fig. 1 and Fig. 2). Although Meishans achieve puberty at a much younger age than do conventional boars, the coincidence between structural and hormonal peaks indicate that there is a strong interdependence and cause-and-effect relationship amongst these characteristics, even in these two very different types of pig. Presumably, the high early postnatal concentrations of gonadotrophins stimulate the marked increase in Leydig cell size, and the increased steroidogenic machinery in the enlarged Leydig cells synthesize and secrete enough steroids to produce the early postnatal peak in serum androgens.

In conventional boars, the general decreases in serum LH and FSH through puberty and into sexual maturity, with perhaps a small transient increase in FSH preceding or coinciding with the onset of sperm production, are not due to decreases in pituitary gonadotrophin content. Indeed, hypothalamic content of $\mathrm{GnRH}$ and pituitary content of FSH and LH increases progressively from birth through puberty in conventional male pigs (McNamara et al., 1985; Lee et al., 1987). It is more likely that the rapid increase in testis size, increasing total Leydig cell mass, and increasing numbers of receptors for both LH and FSH (presumably occurring in Meishans, as has been demonstrated in conventional boars) collectively contribute to rising serum concentrations of androgens during this time frame, i.e., an increase in testicular responsiveness. The increasing serum androgens presumably allow steroid feedback to maintain low serum concentrations of LH during this peripubertal period. Assuming that this occurs, the feedback suppression on gonadotrophins appears to be expressed differently in the Meishan, since LH is suppressed (at least until 13 weeks of age) while FSH increases steadily and markedly at 8 weeks of age and beyond (Fig. 2).

\section{General Reproductive Characteristics in Mature Meishan Boars}

In general, mature Meishan boars exhibit lower body weight and much smaller testicular size than do conventional breeds of boar at comparable ages (Table 2). The number of spermatozoa per ejaculate from Meishan boars is approximately half that of conventional boars (Borg et al., 1993; Gerfen et al., 1994; Huang and Johnson, 1996), but percentage progressively motile spermatozoa, percentage spermatozoa with normal morphology, and other semen quality characteristics are similar, despite major breed differences in mature testis size. In mammals, the number of Sertoli cells determines mature testicular size (Russell et al., 1990; Chubb, 1992), and findings in boars concur with this. Testes of mature Meishans that are approximately half the size of those of conventional boars (Table 1) have substantially fewer Sertoli cells (Okwun et al., 1996a, 1996b). Of significance, daily sperm production per gram of testis (DSP $\mathrm{g}^{-1}$ ) does not differ between Meishan and conventional boars (Table 1); therefore, major differences in total DSP primarily reflect breed differences in paired testis weight. However, the percentage of the testis occupied by seminiferous tubules is 1.4-fold lower in Meishan than in conventional boars (Table 1). Meishan boars produce approximately twice as many spermatozoa per Sertoli cell (Table 1) and almost twice as many elongated spermatids per type A spermatogonium compared with conventional boars to accommodate this change in testis composition (Okwun et al., 1996a, 1996b). The yield of spermatids per type A spermatogonium is a reliable measure of efficiency of spermatogenesis (Berndtson and Igboeli, 1989). Thus, mature Meishan boars produce spermatozoa much more efficiently (per gram of seminiferous tubule, per Sertoli cell, and per spermatogonium) than do conventional boars and appear to achieve this via reduced degeneration of germ cells and spermatids during the spermatogenic process. Although the mechanism that allows Meishan boars to achieve this greater efficiency is unknown, it probably relates to constant exposure of the Sertoli cells to greater concentrations of FSH and androgens. 


\section{Sensitivity to GnRH Stimulation in Mature Meishan and Conventional Boars}

When mature Meishan and conventional boars (Composite $=1 / 4$ Chester White, $1 / 4$ Landrace, 1/4 Large White, 1/4 Yorkshire) of approximately the same body weight (BWT) are challenged with a high (1500 $\mathrm{ng} \mathrm{kg}^{-1}$ BWT) or a low (150 $\mathrm{ng} \mathrm{kg}^{-1}$ BWT) dose of GnRH, both breeds respond with significant increases in serum FSH, LH and testosterone concentrations (Wise et al., 1996), and greater increases occur in response to the high dose of $\mathrm{GnRH}$ in both types of boar. Despite major pretreatment differences in circulating hormone concentrations, the FSH response to GnRH is comparable (i.e., approximately $125 \%$ at low dose and $160 \%$ at high dose above pretreatment values) in Meishan and Composite boars. In Meishan boars, the substantially increased serum concentrations of FSH and LH take longer to return to pretreatment values. Although paired testis size is significantly lower in Meishan boars, serum inhibin concentrations differ minimally at pretreatment and changed little during GnRH challenge (Wise et al., 1996). Accepting the limitations of the radioimmunoassay for the $\alpha$-subunit of inhibin, serum inhibin does not appear to be a primary determinant of high circulating concentrations of FSH in Meishan boars. Thus, under normal physiological conditions, pituitaries of Meishan boars are not functioning under maximal $\mathrm{GnRH}$ stimulation and are not secreting maximal amounts of gonadotrophins. High gonadotrophin concentrations in Meishan boars apparently are under control of a functional and responsive GnRH system.

Interestingly, differences in gonadotrophin secretion during the oestrous cycle are not apparent between females of Meishan and European breeds (Hunter et al., 1996). In contrast to the situation in males, ovariectomized European gilts release greater concentrations of FSH and LH in response to GnRH stimulation than do Meishan gilts and are more responsive in their reduction of FSH concentrations after treatment with pig follicular fluid (inhibin effect; Tilton et al., 1994). A mechanism to explain these sex differences in Meishans is not obvious, but in mice that possess a transgene for human FSH $\beta$, expression is greater in males, but not in females, relative to normal mice (Kumar and Low, 1993).

\section{Negative Feedback Regulation of FSH in Mature Meishan and Conventional Boars}

When mature Meishan and Composite boars that differed 4- to 9-fold in circulating FSH concentrations were castrated, FSH exhibited a postcastration rise, and the rate of this increase $(0-48 \mathrm{~h})$ in both breeds did not differ (Wise et al., 1996). In addition, differences in postcastration FSH concentrations were maintained between breeds through at least 16 days. The pattern of decline in serum testosterone did not differ between breeds after castration, although Meishan boars had greater serum testosterone before castration. These results demonstrate that gonadal hormones exert negative feedback on gonadotrophin concentrations in the mature intact Meishan boar, apparently in a manner similar to that observed in intact conventional boars.

Injection of castrate Meishan and Composite boars with the same dosages of gonadal steroids (testosterone + oestradiol, i.m. on $\mathrm{kg}^{-1}$ BWT basis) was equally effective, in both breeds, at reducing the increased concentrations of serum FSH present in castrates (Wise et al., 1996). The rate of decline in FSH after injection did not differ among the breeds, and the relative degree of suppression by gonadal steroids appeared to be similar. The relative difference in serum FSH before steroid injection continued after steroid treatment. Furthermore, serum FSH began to escape exogenous steroid suppression earlier in Meishan than in Composite castrates. Thus, feedback sensitivity to testicular steroids in these two divergent breeds of boar seems to be fully functional and coordinate within their relative concentrations of circulating hormones. Collectively, these data indicate that the high concentrations of gonadotrophins and androgens in Meishans occur under the control of a hypothalamo-pituitary-gonadal axis that functions responsively but with much higher set points in the Meishan boar. 


\section{Meishan Pituitary Mass and Biological Activity of FSH}

Pituitary size is greater in mature Meishan than in mature Composite boars, and both content and concentration of FSH are substantially higher in anterior pituitaries of Meishan boars (Zanella et al., 1996). The greater expression of the genes for $\alpha$-subunit and for FSH $\beta$ and LH $\beta$ subunits accounts, in part, for the observed differences in gonadotrophin concentrations within pituitaries of Meishan boars. In addition, nucleated pituitary cells that are positive immunocytochemically for FSH or LH (gonadotrophs) have larger cell volumes in Meishan than in Composite boars (Macdonald et al., 1995).

Furthermore, in an in vitro bioassay for FSH activity that utilized a cell line possessing recombinant FSH receptors coupled with a cAMP-responsive system, the activity of pituitary extracts from Meishan and Composite boars is highly correlated with FSH content determined by radioimmunoassay ( $r=0.92$; Macdonald $e t$ al., 1995). In association with this difference in pituitary FSH concentration, gene expression for activin, a stimulator of FSH secretion, is higher in pituitaries of Meishan than in Composite boars ( $\mathrm{Li}$ et al., 1997). In total, the difference in FSH concentrations between Meishan and Composite boars may be due more to differences in activin regulated synthesis rather than to differences in $\mathrm{GnRH}$ regulation of secretion or differences in sensitivity to inhibitors of secretion.

\section{Negative Relationship Between FSH and Mature Testis Size}

When the variation in mature testis size and serum FSH concentration was examined, a negative correlation became apparent in mature Meishan boars as well as in mature Composite and Meishan $\times$ Composite crossbred boars ( $r=-0.74$, Fig. 3; Lunstra et al., 1996). Owing to the positive correlation between mature testis weight and total daily sperm production (TDSP), there is a negative correlation between FSH and TDSP in these boars. Thus, a three times greater serum FSH concentration was associated with $32 \%$ smaller mature testis weight and $33 \%$ lower TDSP. In Meishan $\times$ Composite boars destined to exhibit major differences in serum FSH concentration at maturity, we detected divergence in serum FSH concentrations at 2-8 weeks of age, and this divergence remained during pubertal development (4-6 months of age) and at 1 year of age (Ford et al., 1997). In addition, we have found that serum FSH concentration has a moderate heritability $\left(h^{2}=0.42\right)$ in Meishan $\times$ Composite boars (Rohrer et al., 1997), comparable in magnitude to the heritability of testis size in conventional boars (Young et al., 1986).

The reason for this negative relationship between mature testis size and serum FSH concentration in boars is not clear. In contrast to our findings, FSH secretion (Schinckel et al., 1984; Mariscal et al, 1996) was not influenced by generations of selection for increased testis size in conventional boars (Huang and Johnson, 1996). This lack of an effect on FSH secretion may reflect selection that was not based on testis size at maturity; instead, boars were selected for larger testis size at 150 days of age which would select primarily for earlier pubertal development and secondarily for mature testis size. In contrast to our findings, most other evidence supports a concept that high serum FSH, especially during the early postnatal period, would contribute to greater proliferation of Sertoli cells and result in a larger mature testis size. Treatment of rodents with FSH during early postnatal life causes testicular hypertrophy and increases in numbers of Sertoli cells that persist into adulthood (Meachem et al., 1996). In addition, treatment of conventional boars with FSH from 8 to 40 days of age caused no testicular hypertrophy by 100 days of age, but appeared to delay puberty, to increase the length of seminiferous tubules and the total number of Sertoli cells, and, theoretically, would have increased mature testis size (Swanlund $e t$ al., 1995). The latter study contradicts the association between testis size and high serum FSH in Meishan boars (i.e., earlier puberty and reduced mature testis size) and in conventional breeds of boar (i.e., reduced mature testis size). Moreover, other researchers have begun to question the necessity of FSH for regulation of spermatogenesis (Zirkin et al., 1994). Thus, further studies are needed to clarify relationships between extremes in FSH concentrations and extremes in age at puberty and mature testis size. 


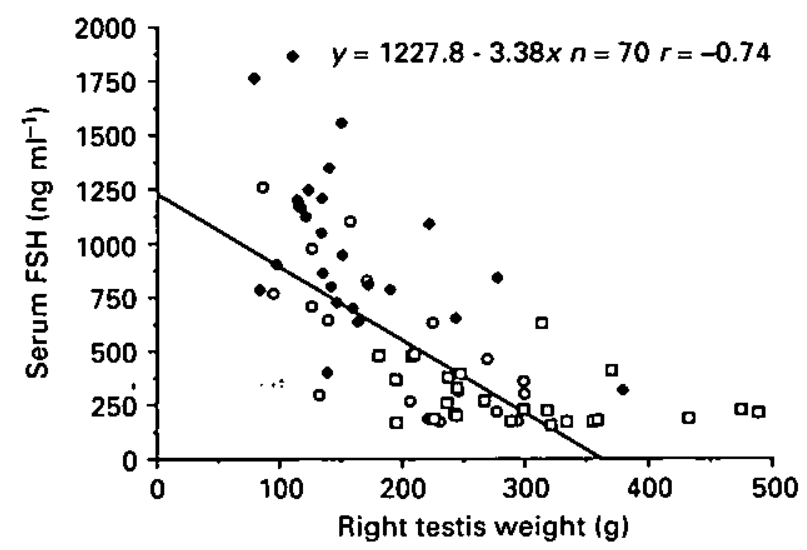

Fig. 3. Relationship between testis size and serum FSH concentration in mature $(\diamond)$ Meishan, $(\square)$ Composite and $(O)$ Meishan $\times$ Composite boars. All boars were $>1$ year of age. Composite boars: 1/4 Chester White, 1/4 Landrace, 1/4 Large White, 1/4 Yorkshire.

Of particular relevance may be that serum TSH concentration is greater and expression of the $\beta$-subunit gene for thyroid-stimulating hormone (TSH- $\beta$ ) in pituitaries is higher in mature Meishan than in conventional boars ( $\mathrm{Li}$ et al., 1996). Sertoli cells have receptors for TSH, and TSH has potency equivalent to FSH for stimulation of androgen binding protein secretion by Sertoli cells (Hutson and Stocco, 1981). Increased serum TSH concentrations (Ford et al., unpublished data) in combination with high FSH concentrations are associated with reduced testis size exhibited by mature boars with high FSH. Early prepubertal treatment of male rodents with propylthiouracil, a compound that blocks T3 and T4 production (hypothyroidism), causes TSH and FSH to remain at low concentrations into adulthood and results in increased numbers of Sertoli cells, increased mature testis size, and increased sperm production (Hess et al., 1993; Simorangkir et al., 1995). The implication from these propylthiouracil studies is that the opposite effect (high concentrations of TSH and FSH) prepubertally would cause reduced numbers of Sertoli cells and smaller adult testis size. Contrary to prediction, mature testis size of conventional boars was not increased by propylthiouracil treatment from 1 to 9 weeks of age (Tarn $e$ al., 1996), but this treatment failed to decrease serum FSH. At present the prepubertal manipulation of FSH and TSH in conventional boars has not duplicated effects on testicular development comparable to those observed in Meishan boars.

\section{Conclusion}

Major endocrine differences and unique differences in the structural and functional efficiency of the testis are exhibited in Meishan boars during pubertal development and at maturity in comparison with boars of conventional breeds. Many fundamental questions remain concerning the factors that control these aspects of reproduction in boars. Why is high FSH secretion throughout development associated with increased spermatogenic efficiency but an unexpected reduction in testis size, while high $\mathrm{LH}$ secretion is associated with predictable increases in Leydig cell size and testicular steroidogenesis? These unusual endocrine and physiological attributes in boars of the highly prolific Meishan breed offer a unique model for further investigation of factors influencing male reproductive function. In particular, can the greater efficiency of spermatogenesis in Meishan boars be introgressed into boars of conventional breeds? Hopefully, future results using this model will provide new insights and contributions to the expansion of our understanding of the physiological basis for the reproductive superiority of hyperprolific pigs. 
The authors thank A. Kruger, P. Sherman and S. Hassler for technical assistance, personnel of USMARC Swine Operations for care of animals, and D. Griess for secretarial assistance. Mention of trade names is necessary to report factually on available data; however, the USDA neither guarantees nor warrants the standard of the product, and the use of the same by USDA implies no approval of the product to the exclusion of others that may also be suitable.

\section{References}

Allrich RD, Christenson RK, Ford JJ and Zimmerman DR (1982) Pubertal development of the boar: testosterone, estradiol-17\%, cortisol and $\mathrm{LH}$ concentrations before and after castration at various ages journal of Animal Science $\mathbf{5 5}$ 1139-1146

Allrich RD, Christenson RK, Fond JJ and Zimmerman DR (1983) Pubertal development of the boar: age-related changes in testicular morphology and in vitro production of testosterone and estradiol-17\% Biology of Reproduction 28 902-909

Bemdtson WE and lgboeli G (1989) Numbers of Sertoli cells, quantitative rates of sperm production, and the efficiency of spermatogenesis in relation to the daily sperm output and seminal quality of young beef bulls American Journal of Veterinary Research $501193-1197$

Bong KE, Lunstra DD and Christenson RK (1993) Semen characteristics, testicular size, and reproductive hormone concentrations in mature Duroc, Meishan, Fengjing, and Minzhu boars Biology of Reproduction 49 515-521

Cheng PL (1983) A highly prolific pig breed of China - the Taihu breed (Parts I and II) Pig News and Information 4 $407-425$

Christenson RK (1993) Ovulation rate and embryonic survival in Chinese Meishan and white crossbred pigs Journal of Animal Science 71 3060-3066

Chubb C (1992) Genes regulating testis size Biology of Reproduction 47 29-36

Colenbrander B, Frankenhuis $M$ and Wensing CJG (1982) Male sexual development In Control of Pig Reproduction pp 3-24; Eds D Cole and G Foxcroft. Butterworth Scientific, London

FlorCruz SV and Lapwood KR (1978) A longitudinal study of pubertal development in boars International joumal of Andrology 1 317-330

Ford J) (1983) Serum estrogen concentrations during postnatal development in male pigs Proceedings of the Society for Experimental Biology and Medicine 174 160-164

Ford JJ, Wise TH and Lunstra DD (1997) Negative relationship between blood concentrations of follicle stimulating hormone (FSH) and testicular size in mature boars journal of Animal Science 75 790-795

Gerfen RW, White BR, Cotta MA and Wheeler MB (1994) Comparison of semen characteristics of Fengjing, Meishan and Yorkshire boars Theriogenology 41 461-469

Haley CS, Lee GJ and Ritchie M (1995) Comparative reproductive performance in Meishan and Large White pigs and their crosses Animal Sciences 60 259-267

Harayama H and Kato S (1992) Changes in motility and morphology of spermatozoa during their transit through the epididymis in Meishan boars at various ages Animal Science Technology 63 462-467

Harayama H, Nanjo I, Kanda S and Kato S (1991) Testicular development in Chinese Meishan boars Theriogenology 36 $637-643$
Hess RA, Cooke PS, Bunick D and Kirby JD (1993) Adult testicular enlargement induced by neonatal hypothyroidism is accompanied by increased Sertoli and germ cell numbers Endocrinology 132 2607-2613

Huang Y.T and Johnson RK (1996) Effect of selection for size of testes in boars on semen and testis traits Joumal of Animal Science 74 750-760

Hunter MG, Biggs C, Foxcroft GR, McNeilly AS and Tilton JE (1993) Comparisons of endocrinology and behavioural events during the periovulatory period in Meishan and Large-White hybrid gilts Joumal of Reproduction and Fertility 97 475-480

Hunter MG, Picton HM, Biggs C, Mann GE, McNeilly AS and Foxcroft GR (1996) Periovulatory endocrinology in high ovulating Meishan sows Journal of Endocrinology 150 141-147

Hutson JC and Stocco DM (1981) Regulation of Sertoli cell function by thyrotropin Biology of Reproduction 25 303-306

Kosco MS, Bolt DJ, Wheaton JE, Loseth KJ and Crabo BG (1987) Endocrine responses in relation to compensatory testicular growth after neonatal hemicastration in boars Biology of Reproduction 36 1177-1185

Kumar TR and Low MJ (1993) Gonadal steroid hormone regulation of human and mouse follicle stimulating hormone $\beta$-subunit gene expression in vivo. Molectular Endocrinology 7 898-906

Lee K-H, Diekman MA, Moss GE and Allrich RD (1987) Pituitary gonadotropins, hypothalamic gonadotropin-releasing hormone, and testicular traits of boars exposed to natural or supplemental lighting during pubertal development Biology of Reproduction 36 1164-1169

Li MD and Enfield FD (1989) A characterization of Chinese breeds of swine using cluster analysis Joumal of Animal Breeding Genetics 106 379-388

Li MD, Matteri RL, Macdonald GJ, Wise TH and Ford JJ (1996) Overexpression of $\beta$-subunit of thyroid-stimulating hormone in Meishan swine identified by differential display Journal of Animal Science 74 2104-2111

Li MD, Macdonald GJ and Ford JJ (1997) Breed differences in expression of inhibin/activin subunits in porcine anterior pituitary glands Endocrinology 138 712-718

Lunstra DD, Ford JJ, Christenson RK and Allrich RD (1986) Changes in Leydig cell ultrastructure and function during pubertal development in the boar Biology of Reproduction 34 145-158

Lunstra DD, Borg KE and Klindt J (1993) Changes in porcine testicular structure during development in Meishan boars Biology of Reproduction 48 (Supplement 1) 126 (Abstract)

Lunstra DD, Ford JJ and Wise TH (1996) Selection for extremes in serum FSH concentrations results in reduced testis size and fertility in Meishan and White composite boars. In Advances in Suine in Biomedical Research Vol. 2 pp. 523-531 Eds ME Tumbleson and LB Schook. Plenum Press, New York 
Macdonald GJ, Wise T, Sluss PM, Lunstra DD and Ford JJ (1995) Differences in pituitary gonadotropins from male pigs representing divergent breeds Biology of Reproduction 52 (Supplement 1) 77 (Abstract)

Mariscal DV, Wolfe PL, Bergfeld EG, Cupp AS, Kojima FN, Fike KE, Sanchez T, Wehrman ME, Johnson RK, Kittok RJ, Ford J and Kinder JE (1996) Comparison of circulating concentrations of reproductive hormones in boars of lines selected for size of testes or number of ovulations and embryonal survival to concentrations in respective control lines Joumal of Animal Science 74 1905-1914

MeNamara M, Vandalem JL, Hennen G, Colenbrander B, MacDonald AA, Van De Wiel D and Meijer JC (1985) The ontogeny of hypothalamic pituitary function in the pig. I Pituitary LH and FSH in the fetus and neonate Molecular and Cellular Endocrinology 39 119-124

Meachem SJ, McLachlan RI, de Kretser DM, Robertson DM and Wreford NG (1996) Neonatal exposure of rats to recombinant follicle stimulating hormone increases adult Sertoli and spermatogenic cell numbers Biology of Reproduction 54 36-44

Okwun OE, Igboeli C, Ford JJ, Lunstra DD and Johnson L (1996a) Sertoli cell number and function, spermatogonial number and yield, and daily sperm production in three breeds of boars Joumal of Reproduction and Fertility 107 137-149

Okwun OE, Igboeli G, Lunstra DD, Ford JJ and Johnson L. (1996b) Testicular composition, number of A spermatogonia, germ cell ratios, and number of spermatids in three different breeds of boars journal of Andrology 17 301-309

Peyrat J-P, Meusy-Dessolle N and Garnier J (1981) Changes in Leydig cells and luteinizing hormone receptors in porcine testis during postnatal development Endocrinology 108 625-631

Rohrer GA, Ford JJ, Wise TH and Young LD (1997) Estimates of genetic correlations between serum FSH concentrations in males and measures of female reproduction in a crossbred Meishan population of pigs Journal of Animal Science 75 (Supplement 1) 31 (Abstract)

Russell LD, Ping Ren H, Sinha Hikim I, Schultze $W$ and Sinha Hikim AR (1990) A comparative study in twelve mammalian species of volume density, volumes, and numerical densities of selected testis components, emphasizing those related to the Sertoli cell American Joumal of Anatomy 188 21-30

Schinckel AP, Johnson RK and Kittok RJ (1984) Testicular development and endocrine characteristics of boars selected for either high or low testis size Journal of Animal Science 58 675-685

Simorangkir DR, de Kretser DM and Wreford NG (1995) Increased numbers of Sertoli and germ cells in adult rat testes induced by synergistic action of transient neonatal hypothyroidism and neonatal hemicastration Journal of Reproduction and Fertility 104 207-213

Swanlund DJ, N'Diaye MR, Loseth KJ, Pryor JL, and Crabo BG (1995) Diverse testicular responses to exogenous growth hormone and follicle-stimulating hormone in prepubertal boars Biology of Reproduction 53 749-757

Tan HS and Raeside JI (1980) Developmental patterns of plasma dehydroepiandrosterone sulfate and testosterone in male pigs Animal Reproduction Science 3 73-81

Tam CY, Rosenkrans CF, Jr and Kirby JD (1996) Effects of 6-N-propyl-2-thiouracil on boars. II Growth and reproductive traits Journal of Animal Science 74 (Supplement 1) 155 (Abstract)

Tilton JE, Biggs C, Hunter MG and Foxcroft GR (1994) Conadotropin secretion in ovariectomized Chinese Meishan and hybrid large white gilts: responses to challenges with estradiol benzoate, gonadotropin-releasing hormone, or porcine follicular fluid Biology of Reproduction 51 963-970

Tran D, Meusy-Dessolle $N$ and Josso $N$ (1981) Waning of anti-Mullerian activity: an early sign of Sertoli cell maturation in the developing pig Biology of Reproduction 24 923-931

Trudeau VL, Meijer JC, Erkens JHF, Van De Wiel DFM and Wensing CJG (1992) Pubertal development in the male pig: effects of treatment with a long-acting gonadotropinreleasing hormone agonist on plasma luteinizing hormone, follicle stimulating hormone and testosterone Canadian Journal of Veterinary Research 56 102-109

van Straaten HWM and Wensing CJG (1977) Histomorphometric aspects of testicular morphogenesis in the pig Biology of Reproduction $17467-472$

van Straaten HWM and Wensing CJG (1978) Leydig cell development in the testis of the pig Biology of Reproduction 18 86-93

Wang RX (1990) Reproductive characteristics of the Fengjing pigs. In Proceedings of Chinese Pig Sympositum Toulouse pp. 6-16 Eds $M$ Molenat and C Legault, , INRA (lnstitut National de la Recherche Agronomique), Jouy-en-Josas Cedex, France

White BR, MeLaren DG and Dzuik PJ (1993) Age at puberty, ovulation rate, uterine length, prenatal survival and litter size in Chinese Meishan and Yorkshire females Theriogenology 40 85-97

Wise T, Lunstra DD and Ford JJ (1996) Differential pituitary and gonadal function of Chinese Meishan and European white composite boars: effects of GnRH stimulation, castration, and steroidal feedback Biology of Reproduction 54 146-153

Young LD, Leymaster KA and Lunstra DD (1986) Genetic variation in testicular development and its relationship to female reproductive traits in swine Joumal of Animal Science 63 17-26

Zanella EL, Ford JJ, Wise T and Hamemik DL (1996) Pituitary relationship of gonadotropins and messenger ribonucleic acid for gonadotropin subunits in white composite and Meishan boars Biology of Reproduction 54 154-159

Zirkin BR, Ewing LL, Kromann N and Cochran RC (1980) Testosterone secretion by rat, rabbit, guinea pig, dog, and hamster testes perfused in vitro: correlation with Leydig cell ultrastructure Endocrinology 107 1867-1874

Zirkin, BR, Awoniyi C, Griswold MD, Russell LD and Sharpe $R$ (1994) Is FSH required for adult spermatogenesis? Joumal of Andrology 15 273-276 